\title{
ELT Students' Perceptions of Classroom Management during Teaching Practice: Difficulties and Solutions
}

\section{Persepsi Mahasiswa Pendidikan Bahasa Inggris tentang Pengelolaan Kelas selama Praktik Mengajar: Kesulitan dan Solusinya}

\author{
Joeang Salsabiltisa De Side, Mohammad Adnan Latief, Ekaning Dewanti Laksmi* \\ Universitas Negeri Malang, Jl. Semarang No. 5 Malang, Jawa Timur, Indonesia \\ *Penulis korespondensi, Surel: ekaning.dewanti.fs@um.ac.id
}

Paper received: 04-02-2021; revised: 16-02-2021; accepted: 28-02-2021

\begin{abstract}
Teaching practice becomes one of the challenges for ELT student teachers to carry out the theories they have learned into practice. In view of the challenges, ELT student teachers of Universitas Negeri Malang may also have difficulties in managing a classroom. Therefore, this study was conducted to know the ELT students' perceptions of classroom management during teaching practice, focusing on the difficulties and solutions. A quantitative with a descriptive research survey was used as the research design. An online questionnaire and interview were used as the instruments to collect the data. The result of this study shows that ELT student teachers 2016 of Universitas Negeri Malang have many difficulties in setting the rules and procedures, especially for group work. The result of the questionnaire depicts that some students break the rules (83.4\%), difficulties in handling students who were not willing to work with their friends (67.9\%), difficulties in ending the teaching and learning activity that reinforces discipline (66.7\%), difficulties in engaging students' interests at the beginning of teaching and learning activity (57.1\%), and difficulties in handling students who bother their friends when they have finished a task (51.2\%). For ELT student teachers who will be doing their teaching practice, it is essential to understand and deepen the knowledge of managing the classroom. Moreover, student teachers need to set clear instructions for group work and negotiate with the students whether they want to make groups by themselves or randomly chosen by the teacher. Lastly, give extensive activities for "disruptive students".
\end{abstract}

Keywords: student teachers, teaching practice, classroom management

\begin{abstract}
Abstrak
Praktik mengajar menjadi salah satu tantangan bagi mahasiswa ELT untuk mengimplementasikan teori-teori yang telah dipelajarinya. Melihat tantangan tersebut, mahasiswa ELT Universitas Negeri Malang sebagai calon guru mungkin juga mengalami kesulitan dalam mengelola ruang kelas. Oleh karena itu, penelitian ini dilakukan untuk mengetahui persepsi mahasiswa ELT tentang pengelolaan kelas selama praktik mengajar, fokus pada kesulitan dan solusi. Penelitian ini menggunakan metode kuantitatif, survei deskriptif. Instrumen yang digunakan untuk mengumpulkan data adalah angket dan wawancara. Hasil penelitian ini menunjukkan bahwa mahasiswa KPL Pendidikan Bahasa Inggris Universitas Negeri Malang tahun ajaran 2016 mengalami banyak kesulitan dalam menetapkan tata tertib dan prosedur di dalam kelas selama praktik mengajar, terutama saat kerja kelompok. Hasil kuesioner menunjukkan bahwa mahasiswa KPL mengalami kesulitan dalam menetapkan aturan dan tata cara kerja kelompok karena ditemukan beberapa siswa yang tidak patuh $(83,4 \%)$, kesulitan dalam menangani siswa yang tidak mau bekerja dengan temannya (67,9\%), kesulitan dalam mengakhiri kegiatan belajar mengajar yang melatih kedisiplinan (66,7\%), kesulitan dalam menarik minat belajar siswa pada awal pembelajaran $(57,1 \%)$, dan kesulitan menangani siswa yang mengganggu temannya saat mereka telah menyelesaikan tugasnya $(51,2 \%)$. Bagi mahasiswa KPL Pendidikan Bahasa Inggris yang akan praktik mengajar, sangat penting untuk memahami dan memperdalam ilmu pengelolaan kelas. Selain itu, mahasiswa KPL perlu memberikan instruksi yang
\end{abstract}


jelas saat kerja kelompok dan bernegosiasi dengan siswa apakah mereka ingin membuat kelompok sendiri atau dipilih secara acak oleh guru. Untuk "siswa yang mengganggu", mahasiswa KPL dapat memberikan tugas tambahan.

Kata kunci: guru siswa, praktik mengajar, manajemen kelas

\section{Background of Study}

Becoming a teacher is a lifetime process. The teachers need to keep improving and developing their professionalisms and competencies through experiences in teaching English. Every teacher has a responsibility to bring students to a more improved level. Therefore, teachers' competencies have powerful effects on students' achievements and outcomes. According to Law No.14 (2005) on Teachers and Lecturers and PP 74 in 2008, the government has formulated four types of teacher competence as listed in the explanation of government regulation No.19 of 2005 on national education standards, namely: Pedagogical, Personality, Professional and Social Competence. Professional competence requires the mastery of teaching materials by teachers that enables them to direct students to fulfill National Standard Competence and actively participate in professional activities such as conferences, seminars, and self-development (Rachmawati, 2017). Personal competence is related to personal qualities that reflect a mature and stable personality, such as wisdom and religious attitudes. An individual who possesses these qualities can serve as a positive role model for students. Social competence is similar to interpersonal competence. It covers the ability of teachers to build harmonious and good relationships with related parties in the teaching field, for example parents, students, colleagues, etc. Thus, the success of the teaching and learning process depends on the teachers' competencies. It requires teachers not only to master the four language skills but also to be excellent in competencies.

Pedagogical competence is related to the ability and willingness to apply attitudes, knowledge, and skills that encourage learning from definite goals and frameworks through the development of sustainable teaching in the best way (Puspitasari, Anugerahwati, \& Rachmajanti, 2017). The skills involved in handling the teaching and learning process are related to pedagogical competence. This includes teachers 'comprehension of the needs of students, teachers' mastery of teaching and learning theories and values, classroom management, curriculum, learning evaluation, and personal reflection. It requires the teachers to not only understand the teaching and learning process, but also carry out the theories involved in the practice.

One of the pedagogical competencies that should be considered is managing a classroom. Managing a classroom deals with creating and maintaining an optimal learning condition to reach the teaching goals. The teachers are expected to create an effective, healthy and attractive learning environment. The classroom management within the roles requires teachers to be sustainably involved themselves in the instructional activities where classroom management instruction has been regarded as an essential part of teachers' preparation in a certain policy related to curriculum implementation. Classroom management is written in the $\mathrm{K}-13$ curriculum regulated by Decree No. 65 signed by the Indonesian Minister of Education and Culture (MoEC, 2013). The classroom management guidance includes 1) standards, rules, and procedures of instruction, 2) classroom condition and situation, and 3) time table or schedule. The 2013 curriculum challenges teachers to implement the guidance in the classroom. Teachers are challenged to manage their classrooms, particularly regarding larger classes, 
technology competencies, and school facilities. However, the teaching and learning process in the standard of the process of the 2013 curriculum is understudied.

It is challenging for the student teachers with the curriculum 2013 to adjust to the classroom, especially big classes, technology updates, and school facilities. The student teachers will be able to share the knowledge that they have learned at the campus with the students and teachers at school. The school could be a laboratory experiment where preservice teachers will react, examine, and evaluate their teaching to improve attitudes, beliefs, and teaching practices (Abdullah, 2019). They will find different types of students, and it is their job to adjust their teaching strategies with the students' needs. Subsequently, the field of teaching practice has an important part in student teachers' education program. It plays a significant role in the development of teaching performance.

Despite taking a long journey to the teaching practice, student teachers will find several difficulties during the teaching practice even with good preparation. The situations do not always match their expectations. A study conducted by Keser and Yavuz (2018) shows a result that different perceptions about 'classroom management' affect the views about the classroom management problems and the strategies employed to overcome these problems. For a significant majority of the participants, classroom management is about how the teacher runs the classroom by forming an ideal class environment to facilitate learning while some of the participants relate the concept with motivation, teacher activities, and discipline. Another important conception of classroom management is classified as the interaction and a relationship between teachers and students by the participants. This research has revealed that student-teachers mostly encounter four main classroom management problems. Therefore, those four problems concerning perception about the term are explained as follows; crowded and noisy classes along with talkative students; unmotivated, bored students disturbing the other students within the classroom setting; problems about the interaction and relationship between students and teachers.

A study by Abdullah (2019) showed that there were some problems faced by pre-service English teachers that are, (a) the pre-service English teachers have poor classroom management, (b) the pre-service English teachers used an ineffective method in teaching grammar, (c) the students' mobile phones distraction during the class, and (d) LCD projector in the classroom was not provided by the schools. To solve this problem, the pre-service teachers were suggested to deepen their knowledge and understanding of managing the class. They also have to explain the tenses by determining the appropriate teaching method or technique in the form of dialogue and conversations. Moreover, the pre-service English teachers could solve the problem by restricting the mobile phone usage during the class and also designing learning media that can make lessons clearer, more effective, and efficient.

Therefore, English teaching practice is not an easy task to undertake. There are always challenges and difficulties that may be encountered during the teaching practice. Furthermore, teaching practice will have an impact on the student teachers since they experience the transition from the role of students to the role of teachers. In view of the challenges of teaching practice, ELT student teachers in Universitas Negeri Malang can also have the same difficulties. Most of the studies above revealed that classroom management was a current difficult issue for student teachers in managing classrooms. They found that English student teachers still lack mastery in the classroom. 
A previous study conducted by Widiati, Suryati and Hayati (2018) stated that the novice teachers' experiences during pre-service teacher education are experiences during the initial years of teaching, challenges in lesson planning, challenges in lesson implementation, challenges in classroom management, and challenges in professional development. In terms of classroom management, the novice teachers reported to have difficulties handling big classes, the time available or provided and used to carry out the duties is very limited, and the heavy hours of teaching. On the other hand, this study focuses on examining the perceptions of ELT student teachers about the difficulties in classroom management during the teaching practice. The variables are taken from the theory of Classroom Management by Marzano, Gaddy, Foseid, Foseid, and Marzano (2005) which are Rules and Procedures, Disciplines and Consequences, and Teacher-student Relationships. Furthermore, the population is limited to the ELT students of Universitas Negeri Malang academic year of 2016. Thus, this study examines the student teachers' perceptions of classroom management during teaching practice at school, especially the difficulties that they found and the solutions.

\section{Method}

This study was conducted by using quantitative with a descriptive research survey. The quantitative approach was used as the research design because it involved a big number of students. A research survey is also used to describe the opinions, beliefs, characteristics, attitudes, preferences, and perceptions of people (Latief, 2017). The data collection was done online due to Corona Virus Disease (COVID-19), with questionnaires and interview guidelines as the instruments.

Consequently, the researcher could not directly collect the data by face-to-face meeting with the respondents. Therefore, after the instruments were validated by the expert, the data collection was done online. The data collection was done after distributing the questionnaire to 127 of the population and 84 of the respondents answered the online questionnaire. The questionnaire distributed to the respondents started on July 27th, 2020, using Google Form online questionnaire. The questionnaire link was shared to ELT students in the eight-semester 2019/2020 through WhatsApp group chat and the data were directly got after the respondents sent their answers. Next, the data were tabulated and analyzed using statistical computation.

After calculating and analyzing the data of the online questionnaire, the researcher classified the respondents which have many difficulties and few difficulties. The respondents were interviewed based on those who have few difficulties in managing the classroom during teaching practice. Furthermore, the respondents were asked whether they were willing to be interviewed or not. To prevent the further spread of the coronavirus, the respondents were asked for the best time and virtual place to do the interview. The researcher interviewed nine respondents through WhatsApp Calls/Video Calls. In addition, the interview took around 15 20 minutes, and the conversations were recorded with the permission given.

The data analysis was carried out from the result of the online questionnaire and from the interview. The data from the online questionnaire were calculated using simple statistical techniques through Microsoft Excel. The system point value of the questionnaire defined from strongly disagree, disagree, agree, and strongly agree ranged from 1 to 4 for 30 question items to identify the ELT student teachers' difficulties. If the respondents chose the answer strongly agree or agree, it means that they have many difficulties. Besides, if the respondents chose the answer to disagree or strongly disagree, it means that they have few difficulties. Based on the 
scale set by the researcher, there were 4 options in each question. Moreover, each part consisted of 10 questions with 10 as the lowest score and 40 as the highest score. If the total score ranged from $10-25$ indicated that the student teachers' have few difficulties. The total score indicated that the student teachers have many difficulties if it is ranged from $26-40$. The student teachers' difficulties were known from the analysis of the total score of each variable that can be seen in Table 1. In addition, the result of the online interview was used to strengthen the findings from the online questionnaire of ELT student teachers' perceptions during teaching practice about classroom management.

Table 1. Score Skill and Interpretation

\begin{tabular}{clcc}
\hline & Variable & Range & Interpretation \\
\hline 1. & Rules and Procedures & $10-25$ & Few Difficulties \\
\cline { 3 - 4 } & & $26-40$ & Many Difficulties \\
\hline \multirow{2}{*}{2.} & Discipline and & $10-25$ & Few Difficulties \\
\cline { 2 - 3 } consequences & Teacher-student & $26-40$ & Many Difficulties \\
\cline { 2 - 3 } & Relationships & $10-25$ & Few Difficulties \\
\hline
\end{tabular}

\section{Finding and Discussion}

The findings of this study are supported by Marzano, et al. (2005) who identified seven elements of effective classroom management and three of them were (1) rules and procedure, (2) discipline and consequences, (3) teacher-student relationships.

\subsection{Rules and Procedure}

Rules and procedures refer to the general expectations or standards and how to communicate the expectations for specific behaviors. There are three sub aspects about rules and procedure that are being discussed, (1) beginning and ending the day; (2) group work; and (3) seat work and teacher-led activities. Based on the result of the questionnaire, the average score of ELT student teachers in answering questions regarding Rules and Procedure is 26.2, which means that they have many difficulties. Hence, the findings below show the sub aspects of rules and procedures.

\subsubsection{Beginning and Ending the Day}

The total number of the respondents is 84 students and from the data gathered through the questionnaire, $40.5 \%$ of the respondents agreed that they have difficulties in conditioning the students while checking their attendance. On the other hand, $59.6 \%$ of the respondents disagreed that they have difficulties.

Moreover, $57.1 \%$ of the respondents agreed that they have difficulties in engaging the students' interests at the beginning of the teaching and learning process. Meanwhile, $42.8 \%$ of the respondents disagreed.

For the statement handling the students when answering the question simultaneously is difficult, $64.3 \%$ of the respondents agreed that they have difficulties. However, only $35.7 \%$ of them disagreed that they have difficulties handling the students when answering the question simultaneously. 
The result of the questionnaire shows that $66.7 \%$ of the respondents agreed with the statement that ending the learning activity that reinforces discipline is difficult. Despite that, $33.4 \%$ of the respondents disagreed that they have difficulties to end the learning activity that reinforces discipline to their students. See Table 2.

Table 2. The Result of ELT Students' Questionnaire on How to Begin and End the Day in Managing Classrooms.

\begin{tabular}{|c|c|c|c|}
\hline Statement & Response & Frequency & Percentage \\
\hline \multirow{2}{*}{$\begin{array}{l}\text { 1. Conditioning the students while checking their } \\
\text { attendance is difficult. }\end{array}$} & Disagree & 50 & $59.6 \%$ \\
\hline & Agree & 34 & $40.5 \%$ \\
\hline \multirow{2}{*}{$\begin{array}{l}\text { 2. Engaging the students' interests at the } \\
\text { beginning of the teaching and learning process } \\
\text { is difficult. }\end{array}$} & Disagree & 36 & $42.8 \%$ \\
\hline & Agree & 48 & $57.1 \%$ \\
\hline \multirow{2}{*}{$\begin{array}{l}\text { 3. Handling the students when answering the } \\
\text { question simultaneously is difficult. }\end{array}$} & Disagree & 30 & $35.7 \%$ \\
\hline & Agree & 54 & $64.3 \%$ \\
\hline \multirow{2}{*}{$\begin{array}{l}\text { 4. Ending the learning activity that reinforces } \\
\text { discipline is difficult. }\end{array}$} & Disagree & 28 & $33.4 \%$ \\
\hline & Agree & 56 & $66.7 \%$ \\
\hline
\end{tabular}

Based on the result of the interview, engaging the students' interests at the beginning of the lesson can be done by doing warming-up activity as fun as possible, like asking a question based on their daily basis or a question related to the topic going to be discussed. Moreover, the student teachers can use quotes to motivate students, songs, or videos, and short games related to the material. For example, "Simon Says" or a simple Total Physical Response game. Besides, set clear rules at the beginning. For instance, when answering questions, raise your hand and talk when the teacher asks you to answer. Lastly, doing a reflection activity is the best way to end the teaching and learning process. It can be in the form of asking questions to check their understanding of what they have learned, giving advice, asking for attention gathers, and praying together.

This is in line with Marzano et al. (2005) that starts the day by allowing students to set their own learning goals for the day based on overall goals you have established. Many effective teachers also give students "sponge" activities to work on - sometimes referred to as the "daily starter" or "daily warm-up" - when they enter the classroom. In addition, ending activities help establish the classroom as a predictable environment for learning. There were a variety of ways to end the day or period, such as homework assignments, answering questions, reflecting on learning, or reminding students to put away supplies.

\subsubsection{Group Work}

Based on the questionnaire responses, $64.3 \%$ of the respondents disagreed that they have difficulties in making a good seating arrangement for group work and only $35.7 \%$ of the respondents agreed that they have difficulties in making a good seating arrangement for group work.

Furthermore, 53.6\% of the respondents disagreed that they have difficulties in giving clear instructions for moving into and out of groups and the rest $46.5 \%$ of the respondents agreed that they have difficulties in giving clear instructions for moving into and out of groups. 
In addition, $83.4 \%$ of the respondents agreed on a statement that some students do not obey the rules during group work. Meanwhile, only $16.7 \%$ of the respondents disagreed that some students do not obey the rules during group work. See Table 3.

Table 3. The Result of ELT Students' Questionnaire of Group Work in Managing Classrooms.

\begin{tabular}{llll}
\hline \multicolumn{1}{c}{ Statement } & Response & Frequency & Percentage \\
\hline 5. It is difficult for me to make a good seating & Disagree & 54 & $64.3 \%$ \\
\cline { 2 - 4 } $\begin{array}{l}\text { arrangement for group work. } \\
\text { 6. I found it difficult to give clear instructions for } \\
\text { moving into and out of groups. }\end{array}$ & Agree & 30 & $35.7 \%$ \\
\cline { 2 - 4 } & Disagree & 45 & $53.6 \%$ \\
\hline $\begin{array}{l}\text { 7. Some students do not obey the rules during group } \\
\text { work. For instance, "Listen to your friends when } \\
\text { they were explaining". }\end{array}$ & Disagree & 14 & $46.5 \%$ \\
\cline { 2 - 4 } & Agree & 70 & $83.4 \%$ \\
\hline
\end{tabular}

Based on the result of the interview, the solution for rules and procedures of group work is that the instruction should be clear and understandable. The rules and procedures are set before the group work or even earlier. After that, ask the students to have a group team randomly by counting numbers so they will always have different groups and let the students know who the members of their groups were. However, if the time is limited the student teachers can group them based on their seating arrangements with the member behind them. Besides, pay attention equally to all the students so that all the members participate.

The findings were supported by Csernica, Hanyka, Hyde, Shooter, Toole, and Vigeant. (2002) suggests that three or four members are more appropriate. Larger groups decrease each member's opportunity to participate and often result in some members not actively contributing to the group. In situations where there is a shorter amount of time available to complete a group task, such as an in-class collaborative learning exercise, it is suggested that smaller groups were more appropriate. Another supporting research conducted by Rezaei (2018) states that the students need their instructors to communicate with them more often and create rules and procedures for students' communications after class. Moreover, instructors should train students in the basics of teamwork and how to work in groups effectively, and they recommend teachers to be very clear in their expectations for group projects.

\subsubsection{Seat Work and Teacher-Led Activities}

Based on the questionnaire responses, $67.9 \%$ of the respondents agreed on a statement that handling students who were not willing to work with other friends is difficult. On the other hand, $32.1 \%$ of the respondents disagreed that they have difficulties in handling students who were not willing to work with other friends.

Along with a statement that handling students who bother their friends when they have finished the task is difficult, $51.2 \%$ agreed with it. Besides, $48.8 \%$ disagreed that they have difficulties handling students who bother their friends when they have finished the task.

Moreover, $48.8 \%$ of the respondents agreed that it is difficult to know whether the students have understood the materials or not. However, $51.2 \%$ of the respondents disagreed that they have difficulties in knowing whether the students have understood the materials or not. See Table 4. 
Table 4. The Result of ELT Students' Questionnaire of Seat Work and Teacher-Led Activities in Managing Classroom.

\begin{tabular}{|c|c|c|c|}
\hline Statement & Response & Frequency & Percentage \\
\hline \multirow{2}{*}{$\begin{array}{l}\text { 8. It is difficult for me to handle students who were } \\
\text { not willing to work with other friends. }\end{array}$} & Disagree & 27 & $32.1 \%$ \\
\hline & Agree & 57 & $67.9 \%$ \\
\hline \multirow{2}{*}{$\begin{array}{l}\text { 9. It is difficult for me to handle students who } \\
\text { bother their friends when they have finished the } \\
\text { task. }\end{array}$} & Disagree & 41 & $48.8 \%$ \\
\hline & Agree & 43 & $51.2 \%$ \\
\hline \multirow{2}{*}{$\begin{array}{l}\text { 10. It is hard for me to know whether the students } \\
\text { have understood the materials or not. }\end{array}$} & Disagree & 43 & $51.2 \%$ \\
\hline & Agree & 41 & $48.8 \%$ \\
\hline
\end{tabular}

Based on the interview result, to make the students focus while working on their seats is to walk around when they were working in groups and ask the students to recheck their works. For students who do not want to work with others, keep grouping them so that they can learn. Talk with the students about the problems, but ask first, negotiate with the students whether they want to make groups by themselves or randomly chosen by the teacher. In addition, for the student who bothers their friends when they have finished the task, it will be a good option to give them extensive activities or extra tasks with a higher level of difficulty. If both strategies do not work, try to invite the student to talk. The student teachers can warn them if they still do so, the score will be reduced. Supported by Çopur (2005) it is advisable to have contingency plans for the early finishers in case they finish the tasks earlier. This contingency plan might be an extra exercise, a handout, or a reading passage. Recently, some of the textbooks have been prepared considering the mixed ability classes and include contingency activities in teacher's books.

\subsection{Discipline and Consequences}

Discipline and consequences refer to the feedback in the form of consequences or rewards that the teachers gave to the students for specific behaviors. There are four subaspects about discipline and consequences that are being discussed which are, (1) Teacher Reaction; (2) Tangible Rewards; (3) Group Contingency; and (4) Direct Cost. Based on the result of the questionnaire, the average score of ELT student teachers in answering questions regarding Discipline and Consequences is 24.4 , which means that they have few difficulties. Hence, the findings below show detailed information about discipline and consequences.

\subsubsection{Teacher Reaction}

Based on the result of the questionnaire, $53.5 \%$ of the respondents disagreed that they have difficulties in giving an appropriate reaction when students were misbehaving. Meanwhile, $46.4 \%$ of the respondents agreed that they have difficulties in giving an appropriate reaction when students are misbehaving.

Moreover, $48.9 \%$ of the respondents disagreed that they show inappropriate reactions to misbehaved students such as, intimidating voice or intimidating eye contact. On the other hand, $51.1 \%$ of the respondents agreed that they show inappropriate reactions to misbehaved students.

In addition, 89.3\% of the respondents disagreed with a statement that giving an appropriate reaction such as giving praise or thumbs up to students who were behaving well 
is difficult. It means that they do not have difficulties. However, only $10.8 \%$ of the respondents agreed with it, which means that they have difficulties in giving an appropriate reaction to students who were behaving well. See Table 5.

Table 5. The Result of ELT Students' Questionnaire of Teacher Reaction in Managing Classrooms.

\begin{tabular}{|c|c|c|c|}
\hline Statement & Response & Frequency & Percentage \\
\hline \multirow{2}{*}{$\begin{array}{l}\text { 1. It is difficult for me to give an appropriate } \\
\text { reaction when students are misbehaving. }\end{array}$} & Disagree & 45 & $53.5 \%$ \\
\hline & Agree & 39 & $46.4 \%$ \\
\hline \multirow{2}{*}{$\begin{array}{l}\text { 2. I show inappropriate reactions to misbehaved } \\
\text { students. For instance, intimidating voices or } \\
\text { intimidating eye contact. }\end{array}$} & Disagree & 41 & $48.9 \%$ \\
\hline & Agree & 43 & $51.1 \%$ \\
\hline \multirow{2}{*}{$\begin{array}{l}\text { 3. It is difficult for me to give an appropriate } \\
\text { reaction to students who were behaving well. For } \\
\text { instance, give praises or thumbs up. }\end{array}$} & Disagree & 75 & $89.3 \%$ \\
\hline & Agree & 9 & $10.8 \%$ \\
\hline
\end{tabular}

The result of the interview shows that verbal cues were needed when the students made a crucial problem and non-verbal cues were used to discipline the students. There are several ways to inappropriate behavior, which are using attention gathers or calling the student's name and asking them what happened, look at the student, give a moment of silence (pregnant pause) and wait until the student stops talking, or simply approach them. Try to stay calm and think about the best countermeasure. This is in line with Memişoğlu (2005) that teachers should act by first considering how their verbal and non-verbal behaviors affect their students. Additionally, Marzano et al. (2005) said that verbal and physical, or non-verbal reactions were simple and straightforward ways to address unacceptable behavior.

\subsubsection{Tangible Rewards}

Based on the result of the questionnaire, $70.3 \%$ of the respondents disagreed with the statement that making a tangible reward for students who perform better in English takes time and $29.7 \%$ of the respondents agreed that it takes time to make a tangible reward for students who perform better in English. Furthermore, $71.5 \%$ of the respondents disagreed that they have difficulties in giving a suitable tangible reward as the age of students. Besides, $28.5 \%$ of the respondents agreed that they have difficulties in giving a suitable tangible reward as the age of students. See Table 6.

Table 6. The Result of ELT Students' Questionnaire of Tangible Rewards in Managing Classroom.

\begin{tabular}{lllll}
\hline & \multicolumn{1}{c}{ Statement } & Response & Frequency & Percentage \\
\hline 4. $\begin{array}{l}\text { It takes time for me to make a tangible reward for } \\
\text { students who perform better in learning English. }\end{array}$ & Disagree & 59 & $70.3 \%$ \\
\cline { 3 - 4 } & Agree & 25 & $29.7 \%$ \\
\hline 5. $\begin{array}{l}\text { I found it difficult to give a suitable tangible } \\
\text { reward as the age of students. }\end{array}$ & Disagree & 60 & $71.5 \%$ \\
\cline { 2 - 4 } & Agree & 24 & $28.5 \%$ \\
\hline
\end{tabular}

The result of the interview shows that basically, positive affirmation such as "great", "good job", "that's awesome", etc. is what the students need at school. Every student deserves to get a reward, it can be in the form of an additional score or point, stationary, and sometimes healthy snacks or drinks. Cahya, Kusnadi, and Anggraeni (2018) stated that the teacher can use tangible rewards as effective ways to raise the motivation of students in English learning. 
The teacher should be more creative and attractive to motivate the students, especially to young learners in English learning. However, giving tangible rewards to students too often is not recommended because the students probably work only to receive a reward.

\subsubsection{Group Contingency}

Based on the result of the questionnaire, $22.7 \%$ of the respondents disagreed that they have difficulties grading the students when they were doing group work. On the other hand, $77.3 \%$ of the respondents agreed that they have difficulties grading the students when they were doing group work. Furthermore, 56\% of the respondents disagreed that they have difficulties setting behavior expectations that the group work follows. Besides, $44 \%$ of them agreed that they have difficulties setting behavior expectations that the group work follows. See Table 7.

\section{Table 7. The Result of ELT Students' Questionnaire of Group Contingency in Managing} Classroom.

\begin{tabular}{lllll}
\hline & \multicolumn{1}{c}{ Statement } & Response & Frequency & Percentage \\
\hline \multirow{2}{*}{ 3. I found difficulties to grade students when they } & Disagree & 19 & $22.7 \%$ \\
\cline { 2 - 4 } & were doing group work. & Agree & 65 & $77.3 \%$ \\
\hline \multirow{2}{*}{4.} & I found difficulties to set the behavior expectation \\
that the group work follows. & Disagree & 47 & $56 \%$ \\
\cline { 2 - 5 } & Agree & 37 & $44 \%$ \\
\hline
\end{tabular}

Based on the result of the interview, the respondents answer that it will be fair if the student teachers grade the students' work based on two things: their participation during the group work (contribution during the process) and how the ideas were written in the group. Each of the members does not receive the same points because some of the students might not work in the same proportion. Thus, it is important for student teachers to actively move in order to evaluate every group's work. Furthermore, add more points to the students who got more average percentages than the other members of the group. This finding is supported by Marzano et al (2005) interdependent group contingency strategies were those in which the entire group gets a reward only when every student in the group meets the expected behavior. Moreover, a dependent contingency strategy is when one student's behavior affects all members of the group. In other words, the student-teacher might use the suggestion of using dependent group contingency to grade the students or reward them based on one's performance that affects the group score. Ascertain that the teacher evaluates every group's work.

\subsubsection{Direct Cost}

Based on the result of the questionnaire, $45.2 \%$ of the respondents disagreed that they have difficulties handling students who do not do their homework. However, 54.8\% of the respondents agreed that they have difficulties handling students who do not do their homework.

Moreover, $38.1 \%$ of the respondents disagreed that they have difficulties handling students who got a lower score. Besides, $61.9 \%$ of the respondents agreed that they have difficulties handling students who got a lower score. In addition, $46.4 \%$ of the respondents disagreed that they have difficulties handling students who were not coming to class. On the other hand, $53.6 \%$ of the respondents agreed that they have difficulties handling students who were not coming to class. See Table 8. 
Table 8. The Result of ELT Students' Questionnaire of Direct Cost in Managing Classroom.

\begin{tabular}{lllll}
\hline & \multicolumn{1}{c}{ Statement } & Response & Frequency & Percentage \\
\hline 5. I have difficulties handling students who do not & Disagree & 38 & $45.2 \%$ \\
\cline { 2 - 4 } do their homework. & Agree & 46 & $54.8 \%$ \\
\hline \multirow{2}{*}{$\begin{array}{l}\text { 6. I have difficulties handling students who got a } \\
\text { lower score. }\end{array}$} & Disagree & 32 & $38.1 \%$ \\
\cline { 2 - 4 } & Agree & 52 & $61.9 \%$ \\
\hline 7. I have difficulties handling students who are not & Disagree & 39 & $46.4 \%$ \\
\cline { 2 - 4 } & coming to class. & Agree & 45 & $53.6 \%$ \\
\hline
\end{tabular}

Based on the interview result, the solution for handling the students who got a lower score or do not do their homework and or coming to class is to treat the students differently. For the ones who forgot to do the homework, asked them to do it outside the classroom, or even give them additional work. It will be the greatest disadvantage for them because they miss the lesson as a consequence. Discussing with the students is also needed. Ask the student to share their problems so that we would meet the solutions. In contrast, if they do not have a solid reason, tell them to go meet their homeroom teacher. Research conducted by Cicek, Ulker, and Karakus (2012) supports the finding that in Turkish education system, students were disciplined in different ways according to the intensity and frequency of misbehavior. Teachers, with a few stages of "warnings" discipline less severe misbehaviors. The "student discipline committee" disciplines more severe and more persistent misbehaviors. If teachers cannot cope with misbehaviors with their efforts, they report the related students to this committee.

\subsection{Teacher-Students Relationships}

Teacher-student relationships refer to the act or behavior to build good communication as signs of the teachers' attitude about the class or an individual student. There are three subaspects about the teacher-student relationship that is being discussed which are (1) demonstrating personal interest in students; (2) behaving equitably and responding affirmatively to questions; also (3) being aware of the needs of different types of students. Based on the result of the questionnaire, the average score of ELT student teachers in answering questions regarding teacher-student relationships is 23.7, which means that they have few difficulties. Hence, the findings below show the detailed information on teacherstudent relationships.

\subsubsection{Demonstrating Personal Interest in Students}

Based on the result of the questionnaire, $70.2 \%$ of the respondents disagreed that remembering the students' current achievement is hard. On the other hand, $29.7 \%$ of the respondents agreed with a statement that remembering the students' current achievement is hard. Moreover, $72.6 \%$ of the respondents disagreed that they have difficulties in building a good relationship with students as an individual. Besides, $27.4 \%$ of the respondents agreed that they have difficulties in building a good relationship with students as an individual. See Table 9. 
Table 9. The Result of ELT Students' Questionnaire of Demonstrating Personal Interest in Students in Managing Classrooms.

\begin{tabular}{lllll}
\hline \multicolumn{1}{c}{ Statement } & Response & Frequency & Percentage \\
\hline 1. & $\begin{array}{l}\text { It is hard for me to remember the } \\
\text { current achievements of students. }\end{array}$ & Disagree & 59 & $70.2 \%$ \\
\cline { 2 - 5 } 2. & $\begin{array}{l}\text { It is difficult for me to build a good } \\
\text { relationship with students as an } \\
\text { individual. }\end{array}$ & Disagree & 61 & 25 \\
\cline { 2 - 4 } & Agree & 23 & $72.6 \%$ \\
\hline
\end{tabular}

The result of the interview shows that building a good relationship with students as an individual can be done through a personal approach. It is essential to remember the students' names and achievements, greet them outside the class, and to know a little bit about the students' personality. Try to know what they have been doing, their hobbies, and what they were interested in by having a conversation. Furthermore, supported by a study by Marzano et al (2005) teachers need to learn about what is important to students, which can be accomplished by interacting with them informally, observing them in various situations and settings, and using instructional activities to solicit information from them. For example, some teachers find time each school day or during a class period to have a "2-minute personal conversation" with their students about nonacademic subjects (Salend, 2007).

\subsubsection{Behaving Equitably and Responding Affirmatively to Questions}

According to the data gathered through the questionnaire, $69 \%$ of the respondents disagreed that they have difficulties moving around the room and making eye contact in order to give equal attention to all students. However, $30.9 \%$ of the respondents agreed that they have difficulties moving around the room and making eye contact in order to give equal attention to all students.

Out of all the respondents, $35.7 \%$ of the respondents disagreed that encouraging students' participation during the teaching and learning process is hard. On the other hand, $64.2 \%$ of the respondents agreed that encouraging students' participation during the teaching and learning process is hard.

Moreover, $76.2 \%$ of the respondents disagreed that they have difficulties in responding to student's incorrect answers without embarrassing them in front of their friends. Besides, $23.8 \%$ of the respondents agreed that they have difficulties in responding to student's incorrect answers without embarrassing them in front of their friends.

Besides, $69 \%$ of the respondents disagreed that they sometimes ignore students' responses. For instance, immediately ask another student to respond without acknowledging the previous student's effort. In contrast, $31 \%$ of the respondents agreed that they sometimes ignore students' responses.

Lastly, $84.5 \%$ of the respondents disagreed with allowing students to give negative comments directly to others during the discussion. Nevertheless, $15.5 \%$ of the respondents agreed that allowing students to give negative comments directly to others during the discussion. See Table 10. 
Table 10. The Result of ELT Students' Questionnaire of Behaving Equitably and Responding Affirmatively to Questions in Managing Classrooms.

\begin{tabular}{llll}
\hline \multicolumn{1}{c}{ Statement } & Response & Frequency & Percentage \\
\hline $\begin{array}{l}\text { 3. It is difficult for me to move around the room and } \\
\text { make eye contact in order to give equal attention } \\
\text { to all students. }\end{array}$ & Disagree & 58 & $69 \%$ \\
\cline { 2 - 4 } & Agree & 26 & $30.9 \%$ \\
\hline $\begin{array}{l}\text { 4. It is hard for me to encourage students' } \\
\text { participation during the teaching and learning } \\
\text { process. }\end{array}$ & Disagree & 30 & $35.7 \%$ \\
\cline { 2 - 4 } & Agree & 54 & $64.2 \%$ \\
\hline $\begin{array}{l}\text { 5. It is difficult to respond to students' incorrect } \\
\text { answers without embarrassing them in front of } \\
\text { their friends. }\end{array}$ & Disagree & 64 & $76.2 \%$ \\
\cline { 2 - 4 } & Agree & 20 & $23.8 \%$ \\
\hline $\begin{array}{l}\text { 6. I ignore students' responses sometimes. For } \\
\text { example, immediately ask another student to } \\
\text { respond without acknowledging the previous } \\
\text { student's effort. }\end{array}$ & Disagree & 58 & $69 \%$ \\
\cline { 2 - 4 } & Agree & 26 & $31 \%$ \\
\hline 7. I allow students to give negative comments & & Disagree \\
directly to others during the discussion. & 71 & $84.5 \%$ \\
\cline { 2 - 4 } & Agree & 13 & $15.5 \%$ \\
\hline
\end{tabular}

Based on the result of the interview, the student teachers' behaviors that indicate attention can be seen through expression and gesture. For instance, eye contact, body movement towards their direction, and nod when they were saying or explaining something, walking around the classroom, and not staying at the same spot from the beginning through the end of the lesson. It is good to repeat the points of the student's explanation with our own words, as it shows attention, and helps the others to get a clearer understanding of what we were talking about. In addition, it also helps to correct their grammatical or pronunciation errors sometimes.

In addition, encouraging the students' participation in the learning process is by asking questions. Mention the student's names to answer questions. Mentioned those who were a little bit passive in the class. Guide the students to feel less burdened by saying that there is no 'wrong' answer, or it is okay to make mistakes as it is a part of learning. In addition, give a compliment to students or prepare rewards like snacks to appreciate each participation, whether the answer is right or wrong. For the students who give incorrect responses, the student teachers need to give a chance to answer the question once again or give them clues. Never say that they were wrong or give negative responses. Furthermore, keep on giving gratitude to the students first to respect their participation in answering the question. Say "It was a good try, but there was a more correct answer." After that, ask other students to answer the question, then compare it with the previous incorrect answer then ask the students again like "What do you think which one is the correct or true answer?".

Tai (2014) stated that body language is important to be used when teachers communicate with students. Communicative English is necessary for students to learn. As a result, teachers should be more active in the classroom teaching. Moreover, supported by Beccles, Kwaah, and Otami (2016), self-confidence in students is a result of teacher actions like recognizing students' effort at attempting to answer questions, motivating students for their efforts, and using positive reinforcement. Teachers need to verbally reward students' efforts, and always recognize and use both correct and incorrect answers from students. This act will make students feel accepted and understand why answers were either correct or incorrect and 
gradually build their self-confidence. Hattie (2012) also said that an optimal classroom climate for learning is one that generates a climate in which it is understood that it is okay to make mistakes because mistakes are the essence of learning.

\subsubsection{Being Aware of the Needs of Different Types of Students}

The data gathered through the questionnaire shows that only $19.3 \%$ of the respondents disagreed that they have difficulties treating passive students to be more active during the teaching and learning process. However, $80.7 \%$ of the respondents agreed that they have difficulties treating passive students to be more active during the teaching and learning process. Furthermore, $31 \%$ of the respondents disagreed that handling aggressive students in the classroom is hard. On the other hand, $69 \%$ of the respondents agreed that handling aggressive students in the classroom is hard. Moreover, $32.3 \%$ of the respondents disagreed that treating socially inept students is hard. Besides, $67.9 \%$ of the respondents agreed that treating socially inept students is hard. See Table 11.

Table 11. The Result of ELT Students' Questionnaire of Being Aware of the Needs of Different Types of Students in Managing Classrooms.

\begin{tabular}{|c|c|c|c|}
\hline Statement & Response & Frequency & Percentage \\
\hline \multirow{2}{*}{$\begin{array}{l}\text { 1. It is difficult to treat passive students to be more } \\
\text { active during the teaching and learning process. }\end{array}$} & Disagree & 16 & $19.3 \%$ \\
\hline & Agree & 67 & $80.7 \%$ \\
\hline \multirow{2}{*}{$\begin{array}{l}\text { 2. It is hard to handle aggressive students in the } \\
\text { classroom. }\end{array}$} & Disagree & 26 & $31 \%$ \\
\hline & Agree & 58 & $69 \%$ \\
\hline \multirow{2}{*}{$\begin{array}{l}\text { 3. It is hard for me to treat socially inept students. } \\
\text { (Clumsy, hard to get along with their friends.) }\end{array}$} & Disagree & 27 & $32.2 \%$ \\
\hline & Agree & 57 & $67.9 \%$ \\
\hline
\end{tabular}

Based on the findings of the interview, the student teachers must know that different students need different treatment, doing a personal approach is the best way. Analyze their special behavior and provide activities within the classroom to suit their problems. For passive or socially inept students, the student teachers need to give much more attention and friendly interaction. Try to reach them personally by asking about their difficulties. Encourage the passive student to participate in the class, for example by asking them to answer questions or to read aloud. On the other hand, for aggressive students, try to ask first their problems and give them less attention that implies the idea of your behavior is not appropriate.

Supported by research conducted by Abdullah, Bakar and Mahbob (2012) that both groups of passive and active students acknowledged the importance of students to speak up in the class. Hence, it is important for the instructor to create a conducive learning environment that will stimulate the students to actively participate in the classroom. In an effort to encourage all students to speak up, the instructors can take several steps such as; (1) Invite the students to speak up, (2) Affirming or valued their contributions matter, (3) Give marks/grade for every active participation, (4) Be skillful in varieties of teaching techniques, (5) Reinforce that it is ok to speak up regardless of what is said to be true or not, and (6) Be approachable and friendly.

\section{Conclusion}

In conclusion, ELT student teachers 2016 of UM have many difficulties in setting the rules and procedures, especially for a group work. The result of the questionnaire depicts that some students break the rules (83.4\%), difficulties in handling students who were not willing 
to work with their friends (67.9\%), difficulties in ending the teaching and learning activity that reinforces discipline (66.7\%), difficulties in engaging students' interests at the beginning of teaching and learning activity (57.1\%), and difficulties in handling students who bother their friends when they have finished a task (51.2\%). For ELT student teachers who will be doing their teaching practice, it is essential to understand and deepen the knowledge of managing classroom. Moreover, student teachers need to set clear instructions for group work and communicate with the students whether they want to make groups by themselves or randomly chosen by the teacher. Lastly, give extensive activities for "distruptive students".

\section{References}

Abdullah, D. Y. 2019. Pre-service English teachers' good teaching practice. Malang. Universitas Negeri Malang.

Abdullah, M. Y., Bakar, N., Mahbob, M. H. (2012). Student's participation in the classroom: What motivates them to speak up? Procedia - Social and Behavioral Sciences 51.

Beccles, C., Kwaah, C., \& Otami, D. 2016. Teacher response model for the management of student answers to teacher questions. International Journal of Education, Learning, and Development, 4(10), 1-14.

Cahya, T., Kusnadi, A. N., \& Anggraeni, A. (2018). The influence of tangible rewards to student's motivation in 4th grade SDN Sinargalih 1 Ciranjang. PROJECT (Professional Journal of English Education), 1(4), 350357.

Cicek, V., Ulker, R., Karakus, M. (2012). Classroom management procedures in US and Turkish kindergarten thru 12th grade public school system: Globalizing American education Ssstem. Energy Education Science and Technology Part B Social and Educational Studies. 4

Çopur, D. S. (2005). Coping with the Problems of Mixed Ability Classes. The Internet TESL Journal, 11(8).

Csernica, J., Hanyka, M., Hyde, D., Shooter, S., Toole, M., \& Vigeant, M. (2002). A practical guide to teamwork, version 1.1. College of Engineering, Bucknell University.

Hattie, J. A. C. (2012). Visible learning: A synthesis of over 800 meta-analyses relating to achievement. London: Routledge.

Keser, K. \& Yavuz, F. (2018). Classroom management problems pre-service teachers encounter in ELT. Cypriot Journal of Educational Science, 13(4), 511-520.

Latief, M.A. (2017). Research methods on language learning: An introduction $6^{\text {th }}$ Ed. Malang: Universitas Negeri Malang.

Law of the Republic of Indonesia Number 14 Year 2005 on Teachers and Lecturers. Uno, H.B. (2012). Professional Education. Jakarta: Earth Literacy

Marzano, R. J., Gaddy, B. B., Foseid, M. C., Foseid, M. P., \& Marzano, J.S. (2005). A handbook for classroom management that works. Alexandria, VA. Association for Supervision and Curriculum Development.

Memişoğlu, S. P. (2005). Teacher behaviors that lead to misbehavior in the classroom. Contemporary Education. $323,32-39$.

MoEC. (2013). The Decree of the Minister of Education and Culture No 65/2013 on the Standards for Primary and Middle Education (Peraturan Menteri Pendidikan Dan Kebudayaan Republik Indonesia Nomor 65/2013 Tentang Standar Proses Pendidikan Dasar Dan Menengah). Jakarta: Kementerian Pendidikan.

Puspitasari, A., Anugerahwati, M., \& Rachmajanti, S. (2017). Teachers pedagogical and professional competences in CLIL-based primary schools in Indonesian context. International Conference on Education (ICE2) 2018: Education and Innovation in Science in the Digital Era.

Rachmawati, D. (2017). Self-concept of EFL pre-service teachers: A reflection from a teacher practicum in Indonesia context. The Journal of English Language Studies, 2(1), 1-18.

Rezaei, A. (2018). Effective group work strategies: Faculty and students' perspectives. Journal of Education and Learning, 7(5), 1-10. 
Salend, S. J. (2007). Creating inclusive classrooms: Effective and reflective practices, 6th Edition. US, PrenticeHall.

Tai, Y. (2014). The application of body language in English Teaching. Journal of Language Teaching and Research, 5(5), 1205-1209.

Widiati, U., Suryati, N., \& Hayati, N. (2018). Unraveling the challenges of Indonesian novice teachers of English. Indonesian Journal of Applied Linguistics, 7(3), 621-629. 